\title{
Analysis of Sukuk Research in Indonesia Bibliometric Approach
}

\author{
Lina Nugraha Rani ${ }^{1}$, Nisful Laila ${ }^{2}$, Dian Filianti ${ }^{3}$, Dwi Wulan Ramadani ${ }^{4}$ \\ ${ }^{1}$ Faculty of Economics and Business, Airlangga University, Airlangga Street No. 4 Surabaya, East Java, \\ Indonesia, linanugraha@ @ feb.unair.ac.id \\ ${ }^{2}$ Faculty of Economics and Business, Airlangga University, Airlangga Street No. 4 Surabaya, East Java, \\ Indonesia, nisful.laila@ feb.unair.ac.id \\ ${ }^{3}$ Faculty of Economics and Business, Airlangga University, Airlangga Street No. 4 Surabaya, East Java, \\ Indonesia, dianfilianti@feb.unair.ac.id \\ ${ }^{4}$ Faculty of Economics and Business, Airlangga University, Airlangga Street No. 4 Surabaya, East Java, \\ Indonesia, dwi.w.r-11@feb.unair.ac.id
}

\begin{abstract}
The concept of sharia-based finance is currently growing rapidly in Indonesia. One form of sharia financial instrument that has been issued by both corporations and the state is the sukuk. Sukuk is one of the most innovative forms of product in the development of the contemporary sharia financial system. It can be concluded that sukuk is an alternative source of funding, especially for the government and corporate companies. The growth of sukuk in Indonesia has increased sharply compared to other Islamic financial instruments, the growth reaching 84\% per year if analyzed from 2001 to 2007. Thus, sukuk has developed into one of the most important mechanisms in increasing finance in the international capital market through an Islamically acceptable structure. This study aims to determine the development of research trends in sukuk in Indonesia published by leading journals on Islamic financial economics. The data analyzed consisted of 47 papers that Scopusindexed research publications. The data is then processed and analyzed using the VOSviewer application to find out the bibliometric map of the development of sukuk research in Indonesia.
\end{abstract}

Keywords: Bibliometric, Indonesia, sukuk, VOSviewer.

\begin{abstract}
Abstrak. Konsep keuangan berbasis syariah saat ini sedang berkembang pesat di Indonesia. Salah satu bentuk instrumen keuangan syariah yang telah diterbitkan baik korporasi maupun negara adalah sukuk. Sukuk merupakan salah satu bentuk produk yang paling inovatif dalam perkembangan sistem keuangan syariah kontemporer. Dapat disimpulkan bahwa sukuk merupakan salah satu alternatif sumber pendanaan, khususnya bagi pemerintah dan perusahaan korporasi. Pertumbuhan sukuk di Indonesia meningkat tajam dibandingkan instrumen keuangan syariah lainnya, pertumbuhannya mencapai $84 \%$ per tahun jika dianalisis dari tahun 2001 hingga 2007. Dengan demikian, sukuk telah berkembang menjadi salah satu mekanisme terpenting dalam meningkatkan pembiayaan di pasar modal internasional melalui struktur yang dapat diterima secara Islam. Penelitian ini bertujuan untuk mengetahui perkembangan tren penelitian sukuk di Indonesia yang diterbitkan oleh jurnal-jurnal terkemuka di bidang ekonomi keuangan syariah. Data yang dianalisis terdiri dari 47 makalah yang terindeks Scopus publikasi penelitian. Data tersebut kemudian diolah dan dianalisis menggunakan aplikasi VOSviewer untuk mengetahui peta bibliometrik perkembangan penelitian sukuk di Indonesia.
\end{abstract}

Kata kunci: Bibliometrik, Indonesia, sukuk, VOSviewer.

\section{INTRODUCTION}

The concept of sharia-based finance is currently growing rapidly. Its assets are currently estimated to touch between USD 1.3 trillion as reported by the rating agency "Standard and Poor's Rating Services". Even in the coming years it is estimated that it will grow to reach 2 trillion US dollars. This shows that the market share of Islamic financial institutions currently reaches $3 \%$, and will grow even greater in the future (Center for International Finance \& Development, 2011).

One form of Islamic financial instrument that has been issued by both corporations and the state is the sukuk. Sukuk have both opportunities and challenges in the realm of Islamic finance today (Adam and 
Thomas, 2004). The development of sukuk can be seen in various countries such as Dubai, Pakistan, Indonesia, England, Egypt, Arabia, and so on (Afshar, 2013).

\section{Background}

In fact, sukuk is not a new thing in Islamic history. This term has been known since the first century Hijriyah. At that time, Muslims used it in the context of international trade. It is used by traders as a document showing financial obligations arising from trading ventures and other commercial activities. In fact, a number of authors state that sakk is the root of the word "cheque" in Latin, which has become something commonly used in contemporary banking transactions (Nazaruddin, 2010).

Sukuk is one of the most innovative product forms in the development of the contemporary Islamic financial system. It can be concluded that sukuk is an alternative source of funding, especially for the government and corporate companies (Ayub, 2007).

Sukuk has now become the strongest segment in Islamic finance. Sukuk are involved in international market trading and can move financial cash flows outside the domestic market. Along with growth, hard work and a balanced development agenda, all countries have the potential to expand the increasing role of Islamic finance in contributing to global growth and financial stability (Ahmed et al., 2014).

The growth of sukuk increased sharply compared to other Islamic financial instruments, the growth reached 84\% per year if analyzed from 2001 to 2007. The most sukuk issued were in the Middle East and Malaysia. Nearly $70 \%$ of the main global sukuk come from Malaysia (Shanmugam and Zahari, 2009).

In its development, The Islamic Jurisprudence Council (IJC) then issued a fatwa supporting the development of sukuk. This prompted the Bahrain Monetary Agency (Bahrain Monetary Agency) to launch a 91-day sukuk salam with a value of 25 million US dollars in 2001 (Zubair, 2012). Global sukuk issuance reached its peak in 2007 with a total issuance of sukuk valued at USD 48.885 billion.

The development of sukuk is strongly supported by regulators and governments in the Gulf and Asia. In 2011, 17 countries were recorded to have issued sukuk. Thus, sukuk has developed into a very important mechanism in increasing finance in the international capital market through an Islamically acceptable structure (Fasa, 2016).

\section{Objective}

Based on data on the development of sukuk investment and research on sukuk in Indonesia, this research on sukuk in Indonesia explains the mapping which is divided into several categories:

1. Author mapping, which explains about the most sukuk paper writers about sukuk in Indonesia.

2. The largest number of institutions that publish sukuk research in Institutions mapping.

3. Country mapping, several clusters of countries that appear to publish the most articles with the theme of sukuk in Indonesia.

4. Keywords that have a larger form indicate that the word is used more in journals related to sukuk in Indonesia.

5. Study also obtained results in the form of an index that is often used by authors and is interrelated in the theme of sukuk in Indonesia which is related to Islamic economics. 


\section{LITERATURE REVIEW}

\section{Background Theory}

\section{Definition of sukuk}

Etymologically, sukuk comes from the word 'Sakk' (صَّل (صنَ) which means document or certificate. Sukuk (صُكُوْك (ص) is a term that comes from Arabic and is a plural form (plural). Sakk is a book that records transaction activities and reports that occur. In the Book of Mu'jam Al Mustholahaat Al Iqtishodiyah Wal Islamiyah, sakk can be interpreted as securities (title deed) (Muhammad, 2000).

In terminology, shakk is a paper or note on which there is an order from someone to pay a certain amount of money to another person whose name is written on the paper specific investment projects or activities. According to Iqbal and Mirakhor (2007), sukuk is a representation of proportional ownership of assets for a certain period of time with risks and rewards associated with cash flow through underlying assets that are in the hands of investors.

Meanwhile, the Fatwa of the National Sharia Council (DSN) defines sukuk as a long-term securities based on sharia principles issued by issuers to pay income to sharia bond holders in the form of profit sharing, margins and fees, as well as repay bond funds at maturity (DSN MUI, 2003). According to the Law on State Sharia Securities (SBSN) sukuk are securities issued based on sharia principles, as evidence of the share of participation in SBSN assets, both in rupiah and foreign currencies. The party that issues state sukuk is a legal entity established under the provisions of the law to issue sukuk. Its assets are state-owned goods that have economic value which are used as the basis for issuing state sukuk (UU SBSN, 2010).

In general, sukuk is a stable, tradable, income-supporting asset and a certificate of trust that is compliant with sharia. The main condition why this sukuk is issued is as a counterweight to the wealth contained in the balance sheets of the government, monetary authorities, companies, banks and financial institutions as well as other forms of entities that mobilize public funds. Issuers or parties that issue sukuk can come from government institutions, private companies, financial institutions, or monetary authorities.

\section{Development of sukuk in Indonesia}

Currently, the development of sukuk in Indonesia and the market absorption of them are very encouraging. As a Muslim-populated country in the world, the interest of the public and financial institutions to make sukuk as part of their portfolio looks very significant (Suryomurti, 2011).

Based on the issuer or institution that issued it, sukuk can be divided into two types, namely: (1) corporate sukuk; (2) sukuk negara (sovereign sukuk). Corporate sukuk are sukuk issued by corporations or companies, both private companies and state-owned enterprises. Sukuk negara (sovereign sukuk) are sukuk issued by the government, in this case the Ministry of Finance of the Republic of Indonesia.

Sukuk in Indonesia were first issued by PT Indonesian Satellite Corporation (Indosat) in September 2002 with a value of Rp 175 billion. Indosat's steps were followed by other large companies. The value of corporate sukuk issuance until the end of 2008 reached 4.76 trillion. Meanwhile, the structure of the sukuk used in the 2002-2004 period was dominated by mudharabah amounting to Rp 740 billion (88\%), the remaining ijarah amounting to Rp 100 billion (12\%),194 trillion (92\%), the remaining mudharabah amounted to Rp 200 billion (8\%) (Fatah, 2011).

Sukuk have experienced rapid development both in quantity and quality. However, the application of state sukuk (sovereign sukuk) is not as applicable as the application of private sukuk (corporate sukuk). There are several urgent obstacles to be addressed, such as fiscal and legislative issues (Yaumudin, 2008). Thus, the issuance of a new government sukuk was carried out after the issuance of the law on State Sharia Securities (SBSN) in 2008. Sukuk issued by the state (sovereign sukuk) refer to the following laws and regulations: 
a. Law No.19 of 2008 concerning State Sharia Securities (SBSN);

b. Government Regulation No. 56 of 2008 concerning SBSN Issuing Companies;

c. Government Regulation No. 57 of 2008 concerning the Establishment of Indonesian State Sharia Securities Issuing Companies.

\section{Types of sharia bonds (sukuk)}

According to AAOIFI (the Accounting and Auditing Organization of Islamic Financial Institutions) there are twelve types of sukuk. The classification of these types of sukuk follows the types of financing in financial assets suggested by Islam. Based on financial asset contracts in the secondary market classifies sukuk into two categories (Tariq, 2004), namely:

1. Trading Sukuk

There are several sukuk that can be traded including: First sukuk mudharabah, namely sukuk issued based on an agreement or mudharabah contract in which one party provides capital (rab al-Mâl) and the other party has expertise (mudharib), the profits from the cooperation are divided based on the profit sharing percentage that has been agreed at the beginning of the transaction, and the losses incurred are fully borne by the owners of the capital (Al-Barwary, 2007). The two musharaka sukuk are sukuk issued based on a musyarakah agreement or contract in which two or more parties work together to combine capital to build new projects, develop existing projects, or finance business activities. Profits and losses that arise are shared in accordance with the amount of each capital participation (Al-Barwary, 2007).

The three ijârah sukuk are sukuk issued based on an ijarah agreement or contract in which one party acts alone or through a representative to sell or lease the beneficial rights of an asset to another party based on the agreed price and period, without being followed by the transfer of assets. Sukuk ijarah is divided into ijarah al-Muntahiyabi al-Tamlîk (Sale and Lease Back) and ijarah Headlease and sublease (Adam and Thomas, 2004).

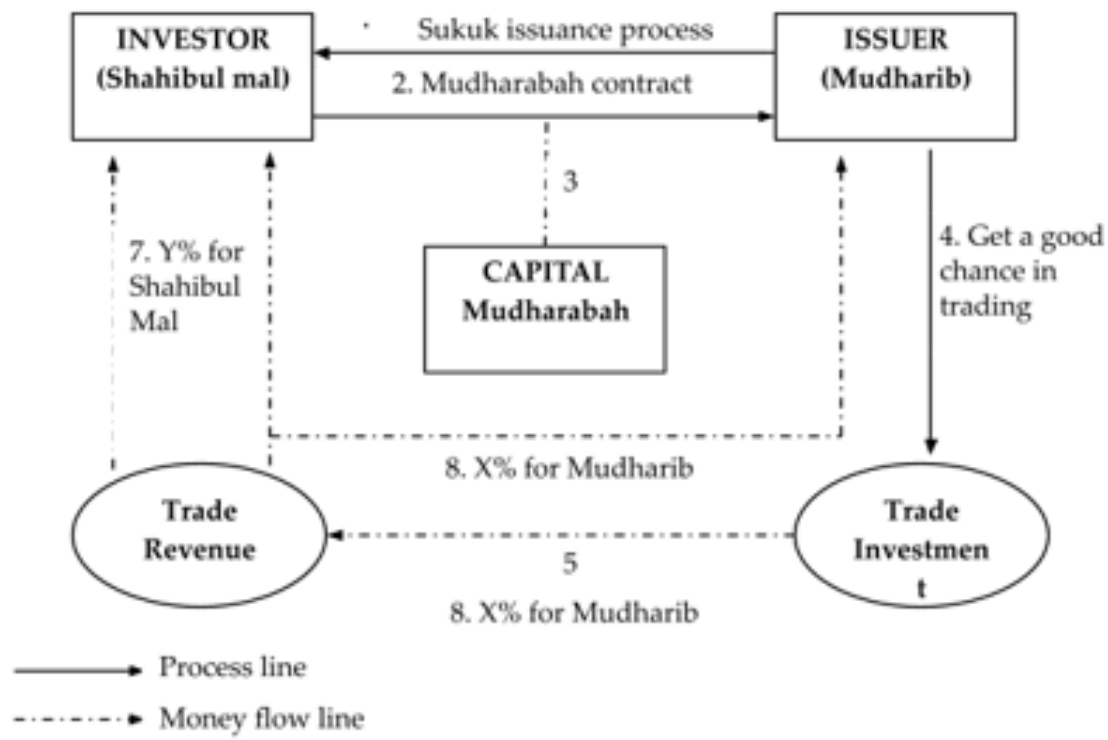

Source: Nazaruddin, 2010.

Figure 1 Sukuk mudharabah scheme model 


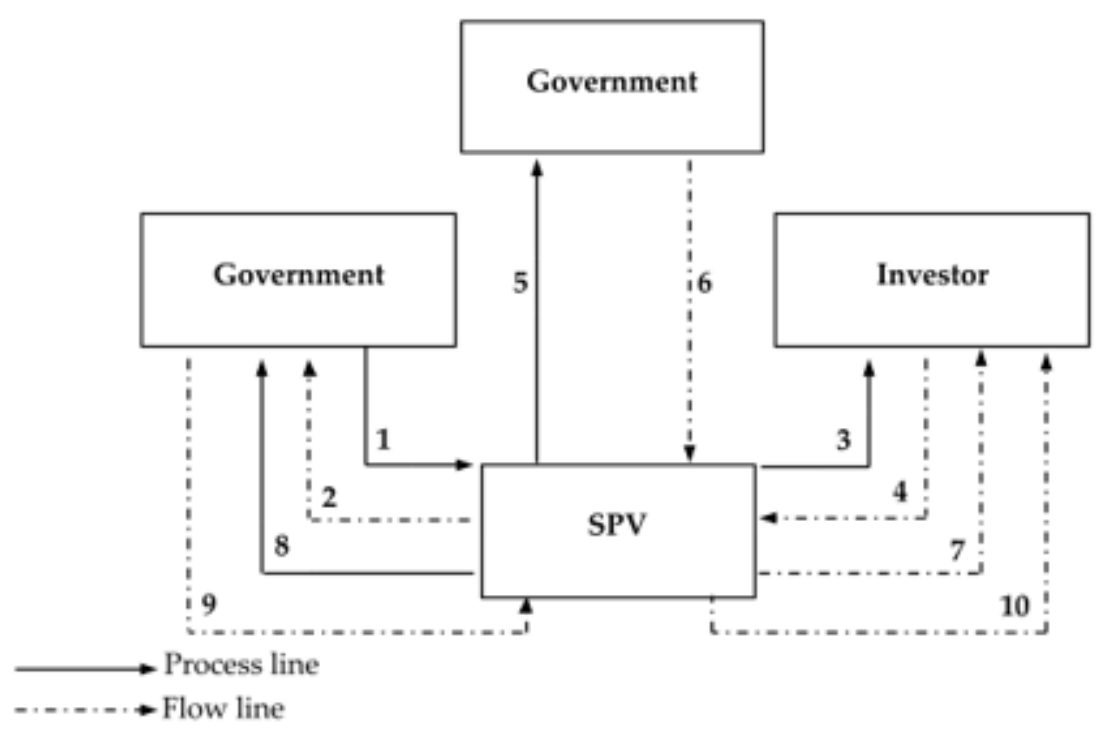

Source: Nazaruddin, 2010.

Figure 2 Sukuk ijarah scheme model

2. Non-tradable Sukuk

Sukuk that cannot be traded include: First, Istishna and/or murabahah sukuk: increasing debt ownership obtained from the istishna and or murabahah financing types. For example, road construction that costs US\$110 million must be returned without the principle of differentiation and discount (coupon). This amount of funds can be converted into nontradable debt certificates that are similar to zero-coupon bonds in some of their features. As it is stated that Islam forbids trading in debt, this certificate cannot be traded. Second, sukuk salam: in this form, funds are paid in advance and the commodity becomes debt. Funds can also be in the form of certificates that represent debt. This certificate is also non-tradable.

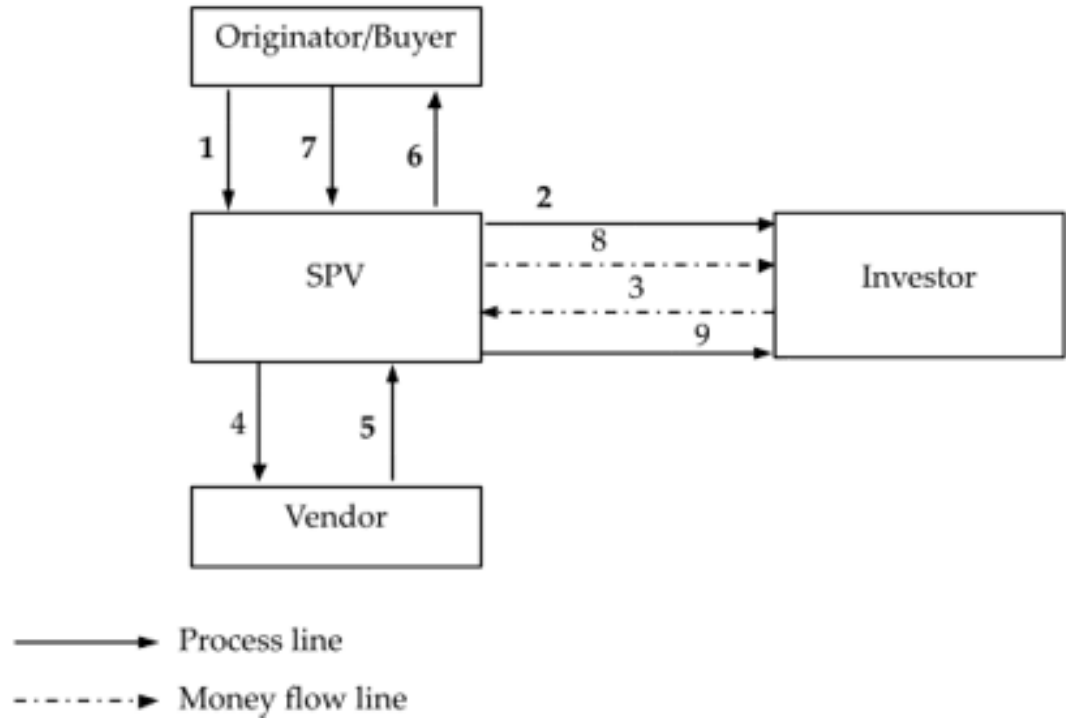

Source: Nazaruddin, 2010.

Figure 2 Sukuk murabahah scheme model

In 2004 AAOIFI noted that the al-Ijarah sukuk which is based on the principle of leasing transactions (lease transactions) is the most common form and is widely used by Islamic and non-Islamic countries. Apart from that, there is also a bitsaman al-Ajl sukuk which is based on the principle of murabahah. This sukuk is very popular in Malaysia, although it is rarely found in Middle Eastern 
countries. Meanwhile, the financing for the development of sukuk-Istishna real estate is the most sought after by investors (Yaumudin, 2008).

\section{Previous Studies}

Table 1 Most cited articles in 2010 to 2021

\begin{tabular}{|c|c|c|c|c|c|}
\hline Rank & Title & Author & Year & Journal & Total \\
\hline 1. & $\begin{array}{l}\text { Sukuk issuance and information } \\
\text { asymmetry: Why do firms issue } \\
\text { sukuk? }\end{array}$ & Nagano, M. & 2017 & $\begin{array}{l}\text { Pacific Basin Finance } \\
\text { Journal } \\
\text { 42, pp. 142-157 }\end{array}$ & 20 \\
\hline 2. & $\begin{array}{l}\text { Current issues in Islamic banking } \\
\text { and finance: Resilience and } \\
\text { stability in the present system }\end{array}$ & Venardos, A.M. & 2010 & $\begin{array}{l}\text { Current Issues in } \\
\text { Islamic Banking and } \\
\text { Finance Resilience and } \\
\text { Stability in the Present } \\
\text { System } \\
\text { pp. } 1-315\end{array}$ & 19 \\
\hline 3. & $\begin{array}{l}\text { Who issues sukuk and when?: An } \\
\text { analysis of the determinants of } \\
\text { Islamic bond issuance }\end{array}$ & Nagano, M. & 2016 & $\begin{array}{l}\text { Review of Financial } \\
\text { Economics } \\
31 \text {, pp. } 45-55\end{array}$ & 14 \\
\hline 4. & $\begin{array}{l}\text { Green bonds for financing } \\
\text { renewable energy and energy } \\
\text { efficiency in South-East Asia: a } \\
\text { review of policies }\end{array}$ & $\begin{array}{l}\text { Azhgaliyeva, } \\
\text { D., Kapoor, } \\
\text { A., Liu, Y. }\end{array}$ & 2020 & $\begin{array}{l}\text { Journal of Sustainable } \\
\text { Finance and Investment } \\
10(2) \text {, pp. 113-140 }\end{array}$ & 10 \\
\hline 5. & $\begin{array}{l}\text { Financial integration between } \\
\text { sukuk and bond indices of } \\
\text { emerging markets: Insights from } \\
\text { wavelet coherence and } \\
\text { multivariate-GARCH analysis }\end{array}$ & $\begin{array}{l}\text { Bhuiyan, } \\
\text { R.A., Rahman, } \\
\text { M.P., Saiti, } \\
\text { B., Mat Ghani, } \\
\text { G. }\end{array}$ & 2018 & $\begin{array}{l}\text { Borsa Istanbul Review } \\
18(3), \text { pp. } 218-230\end{array}$ & 10 \\
\hline 6. & $\begin{array}{l}\text { Co-movement dynamics between } \\
\text { global sukuk and bond markets: } \\
\text { New insights from a wavelet } \\
\text { analysis }\end{array}$ & $\begin{array}{l}\text { Bhuiyan, } \\
\text { R.A., Rahman, } \\
\text { M.P., Saiti, } \\
\text { B., Mat Ghani, } \\
\text { G. }\end{array}$ & 2019 & $\begin{array}{l}\text { International Journal of } \\
\text { Emerging Markets } \\
\text { 14(4), pp. 550-581 }\end{array}$ & 7 \\
\hline 7. & $\begin{array}{l}\text { Islamic bond announcement: Is } \\
\text { there any effect on returns? }\end{array}$ & $\begin{array}{l}\text { Fauzi, F., Foo, } \\
\text { D., Basyith, A. }\end{array}$ & 2017 & $\begin{array}{l}\text { Global Business } \\
\text { Review } \\
\text { 18(2), pp. 327-347 }\end{array}$ & 6 \\
\hline 8. & $\begin{array}{l}\text { Sukuk fund issuance on sharia } \\
\text { banking performance in Indonesia }\end{array}$ & $\begin{array}{c}\text { Atika, } \\
\text { A., Saraswati, } \\
\text { D., Heriyati, } \\
\text { C.H., } \\
\text { (...), Rossanty, } \\
\text { Y., Nasution, } \\
\text { M.D.T.P. }\end{array}$ & 2018 & $\begin{array}{l}\text { International Journal of } \\
\text { Civil Engineering and } \\
\text { Technology } \\
\text { 9(9), pp. 1531-1545 }\end{array}$ & 5 \\
\hline 9. & $\begin{array}{l}\text { Is "not-real" price lawful? : The } \\
\text { case of Islamic (sukuk) mutual } \\
\text { funds in Indonesia during } \\
\text { financial crisis }\end{array}$ & Siswantoro, D. & 2012 & $\begin{array}{l}\text { Journal of Islamic } \\
\text { Accounting and } \\
\text { Business Research } \\
\text { 3(2), pp. 163-177 }\end{array}$ & 5 \\
\hline 10. & $\begin{array}{l}\text { Islamic stock market and sukuk } \\
\text { market development, economic } \\
\text { growth, and trade openness (the } \\
\text { case of Indonesia and Malaysia) }\end{array}$ & $\begin{array}{l}\text { Muharam, } \\
\text { H., Anwar, } \\
\text { R.J., Robiyanto, } \\
\text { R. }\end{array}$ & 2019 & $\begin{array}{l}\text { Business: Theory and } \\
\text { Practice } \\
\text { 20, pp. 196-207 }\end{array}$ & 4 \\
\hline
\end{tabular}

Table 1 shows the 10 most cited articles related to sukuk in Indonesia. The first article, namely Sukuk issuance and information asymmetry: Why do firms issue sukuk? (Nagano, 2017), was quoted at most 20 times. This article examines the factors that prompted bank borrowers to issue sukuk instead of 48 
conventional debt securities in Malaysia and Indonesia from 2000 to 2014. First, the empirical results suggest that bank borrowers are likely to approach the sukuk market as funding size grows and if firms are valued tall. Second, it is found that under high information asymmetry, companies with high stock prices and large demand for funds prefer to issue sukuk over conventional debt. It can be concluded that companies use the sukuk market as an intermediary funding market when the demand for funding is too large to borrow from banks and the information asymmetry is too high for them to approach the conventional debt market.

The article that ranks second is Current issues in Islamic banking and finance: Resilience and stability in the present system (Venardos, 2010) is an article cited 19 times. This article is about the phenomenal development around the world over the last decade regarding Islamic banking and finance which has attracted a lot of attention across Southeast Asia, on the successful platform of economic growth, proving to be a gateway for Middle Eastern petrodollar investment to two major emerging markets namely the Indian market. and China.

The article in third place, namely Who issues sukuk and when?: An analysis of the determinants of Islamic bond issuance (Nagano, 2016), is an article cited 14 times. This article discusses the differences between Islamic bond issuers (sukuk) and conventional debt and equity issuers. An international comparative analysis of these three types of securities issuers yields three main insights. First, accessibility to the sukuk market is very important in choosing a sukuk issuance; other determinants will not encourage the use of sukuk, unless these requirements are met first. Second, the low level of financial constraints on companies encourages the issuance of sukuk, after the issuer's accessibility conditions to the sukuk market are met. Third, the company's undervaluation in the preissuance period also encouraged the issuance of sukuk, after the issuer's sukuk market accessibility conditions were met. Taken together, we conclude that it is preferable to issue sukuk along with market timing, once the market accessibility pecking-order conditions are met.

\section{METHOD}

\section{Data}

This study uses data on publication of papers sourced from various journals from 2010-2021 with a research themed sukuk in Indonesia. Data collection is done through searching for articles indexed by the Google Scholar database, the search is done by typing the keyword 'Sukuk in Indonesia', then selected papers that are relevant to the sukuk research theme, for journal criteria that are filtered and processed in software indexed by Google Scholar only journals that are equipped with DOI. From the search results, there are 47 articles published from 2010-2021. The data in the form of topics used in the publication of the sukuk in Indonesia themed paper were analyzed using Microsoft Excel 2010.

\section{Model Development}

To build the map, VOSviewer uses the VOS mapping technique, where VOS stands for visualization similarity. For previous studies where VOS mapping technique was used. VOSviewer can display maps constructed using appropriate mapping techniques. Therefore, this program can be used to display maps built using the VOS mapping technique and display maps built using multidimensional scaling techniques. VOSviewer runs on many hardware and operating system platforms and can be started directly from the internet.

\section{Method}

The trend of publication development on the sukuk in Indonesia theme was analyzed using VOSviewer software. The computer program that was introduced was called VOSviewer. VOSviewer is a program developed for creating and viewing bibliometric maps. This program is available free of charge to the bibliometric research community (see www.vosviewer.com). VOSviewer can create 
author maps or journals based on co-citation data or create keyword maps based on shared incident data. The program offers a viewer that allows bibliometric maps to be examined in detail.

\section{RESULTS AND DISCUSSION}

\section{Results}

The following is a table that shows the collection of documents used in research with the theme sukuk in Indonesia in Islamic economic research. Of the total 47 documents used, they are divided into 3 types of documents, including journal articles (38 documents), anthology/book chapters (2 documents), and conference papers (7 documents).

Table 2 Document types

\begin{tabular}{clc}
\hline No & Document Types & Number of Articles \\
\hline 1 & Journal article & 38 \\
2 & Book chapter & 2 \\
3 & Conference Paper & 7 \\
\hline & Total & $\mathbf{4 7}$ \\
\hline
\end{tabular}

Based on the results of grouping the types of documents above, the type of document that is most widely used as research subjects with the theme of sukuk in Indonesia is documents in the form of journal articles with a percentage of $80.85 \%$ or as many as 38 documents. Meanwhile, the least amount of documents used is in the form of book chapters amounting to $4.25 \%$ or as many as 2 documents. This shows that the references used are quite valid because most of them come from documents in the form of scientific journals.

\section{Bibliometric graph analysis}

Bibliometrics is based on the calculation and statistical analysis of scientific outputs in the form of articles, publications, citations, patents, and other more complex indicators. It is an important tool in evaluating research, laboratory and scientist activities, as well as scientific specialization and country performance. The report, after setting the background for bibliometric development, presents the database from which the bibliometric was created, as well as the main indicators used.

To explore the results of the meta-analysis, in this section a visual mapping chart from 47 journals published by sukuk in Indonesia will be presented. The results of the keyword mapping analysis become the basis for mapping together important or unique terms contained in certain articles. Mapping is a process that enables one to recognize elements of knowledge and their configuration, dynamics, interdependencies and interactions.

Related to bibliometrics, science mapping is a method of visualizing the field of science. This visualization is done by making a landscape map that can display topics from science (Royani et al., 2013). The results of network visualization from 47 word map journals with the theme sukuk in Indonesia can be seen:

1. Bibliometric Author Mapping

Using the VOSviewer software, we found the author's bibliometric mapping as shown in the following Figure 4. The bigger the shape and the brighter the color, it indicates that the author is publishing more and more of his writings related to Sukuk in Indonesia. 


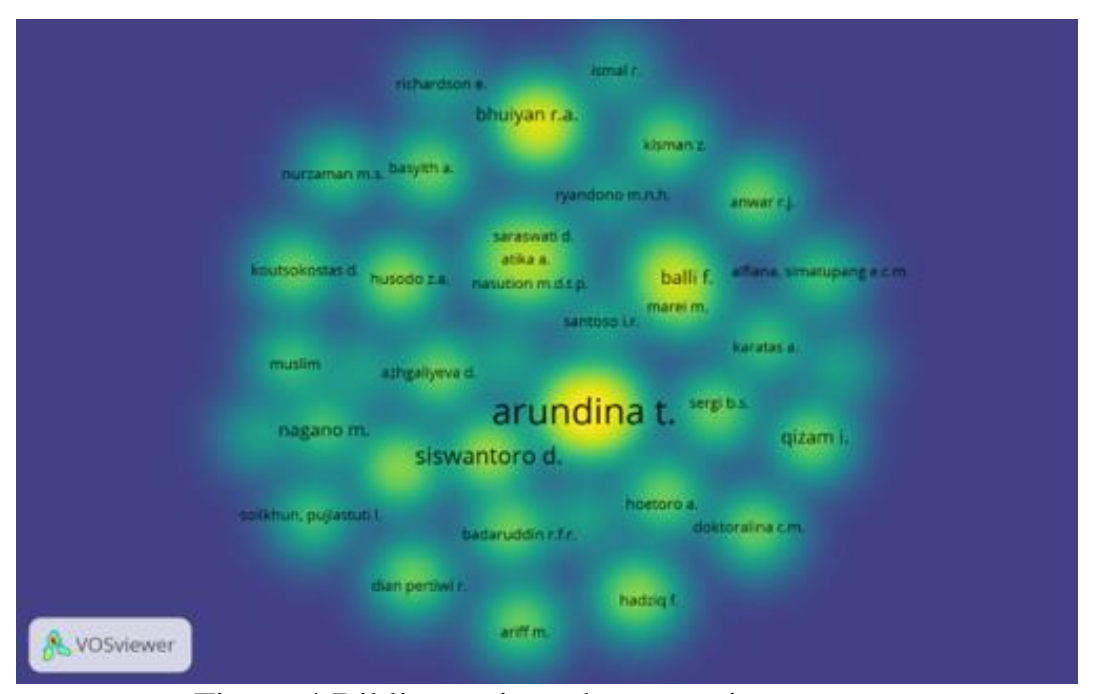

Figure 4 Bibliometric author mapping

The appearance of cluster density depends on the level of yellow light brightness. This identifies that the yellow color on the map depends on the number of items associated with other items. This section is useful for getting an idea of the general structure of a bibliometric map by paying attention to which parts of the light are considered important to analyze. From the map, it is possible to interpret the authors who have published the most.

In general, each researcher has different tendencies. Some writes are indexed as a single author, others co-author with other researchers so that multiple clusters appear which are indicated with different densities. However, the authors with a fairly large density indicated that they published more research on the theme of sukuk in Indonesia than those with a lower density, so this result can be used as a reference for future researchers.

Based on these results, the bigger and brighter the name of the author, the more papers he published. The author most published publications related to the theme of sukuk in Indonesia based on bibliometric mapping, namely Arundina T.

2. Bibliometric Institutions Mapping

In bibliometric analysis, the author's institution can be seen from which institution they come from. Through these results, we were able to interpret the institutions that wrote the most publications.

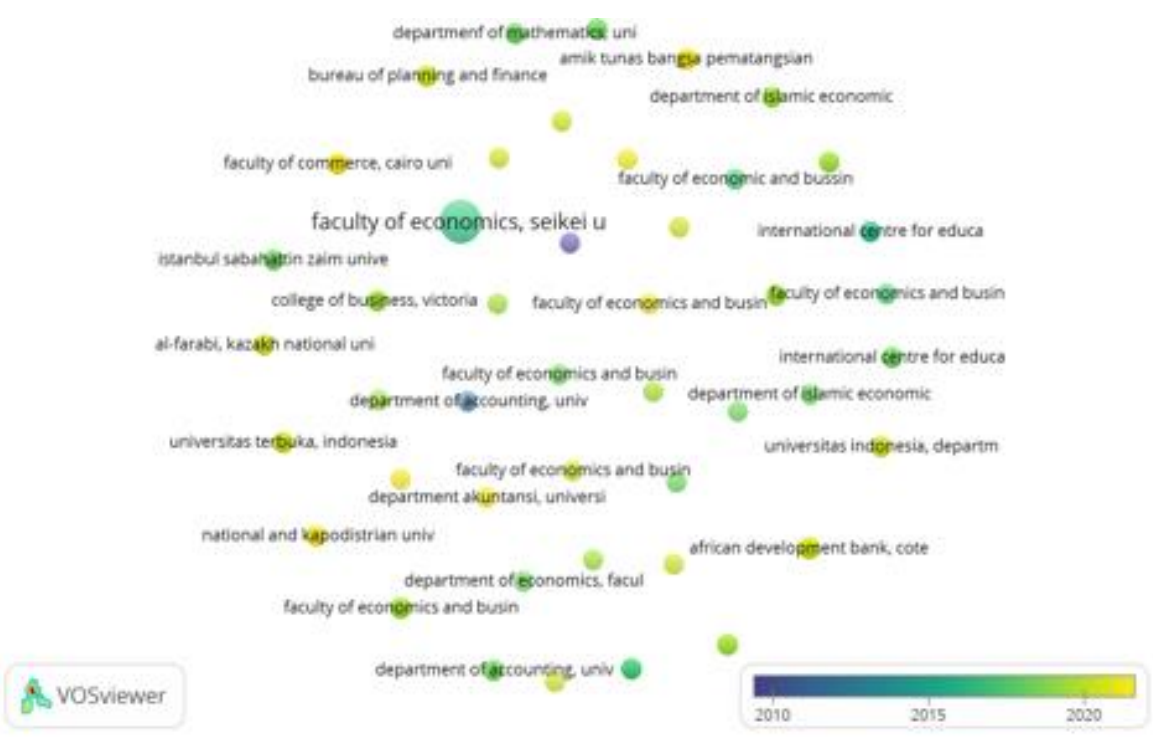

Figure 5 Bibliometric institutions mapping 
Based on the Figure 5, the cluster of institutions seen with large circles shows how productively these institutions have contributed in publishing papers with the theme sukuk in Indonesia. The largest number of institutions is calculated from the number of publications and the number of links to other institutions, where an author can write many papers in different journals.

The most popular institutions are calculated based on the number of publications and the number of links to other institutions, where a paper writer can write many papers in different journals. The most well-known ranking of institutions shown by the results of bibliometric mapping is the Faculty of Economics, Seikei University, 3-3-1 Kichijoji Kitamachi, Musashino City, Tokyo 180-8633, Japan.

3. Bibliometric Country Mapping

Furthermore, the visualization of the journal publisher mapping is illustrated in the bibliometric image of the journal source below. Based on the picture, it can be seen that several clusters of countries that appear to publish the most articles with the theme of sukuk in Indonesia.
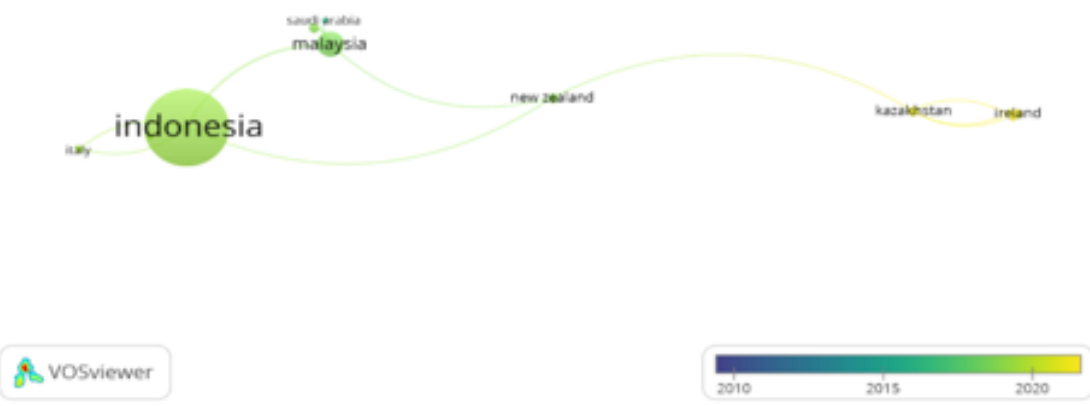

Figure 6 Bibliometric country mapping

Based on the Figure 6, the larger the circle of the publishing country, the more papers that country publishes. It can be seen that Indonesia has the brightest light. This means that Indonesia publishes the most sukuk in Indonesia-themed papers compared to other countries.

4. Bibliometric Keyword Mapping

VOSviewer can also find a bibliometric mapping of the most widely used keywords in the sukuk in Indonesia theme related to Islamic economics. The bibliometric mapping of the keywords used can be seen in the image below. Keywords that have a larger form indicate that the word is used more in journals related to sukuk in Indonesia.

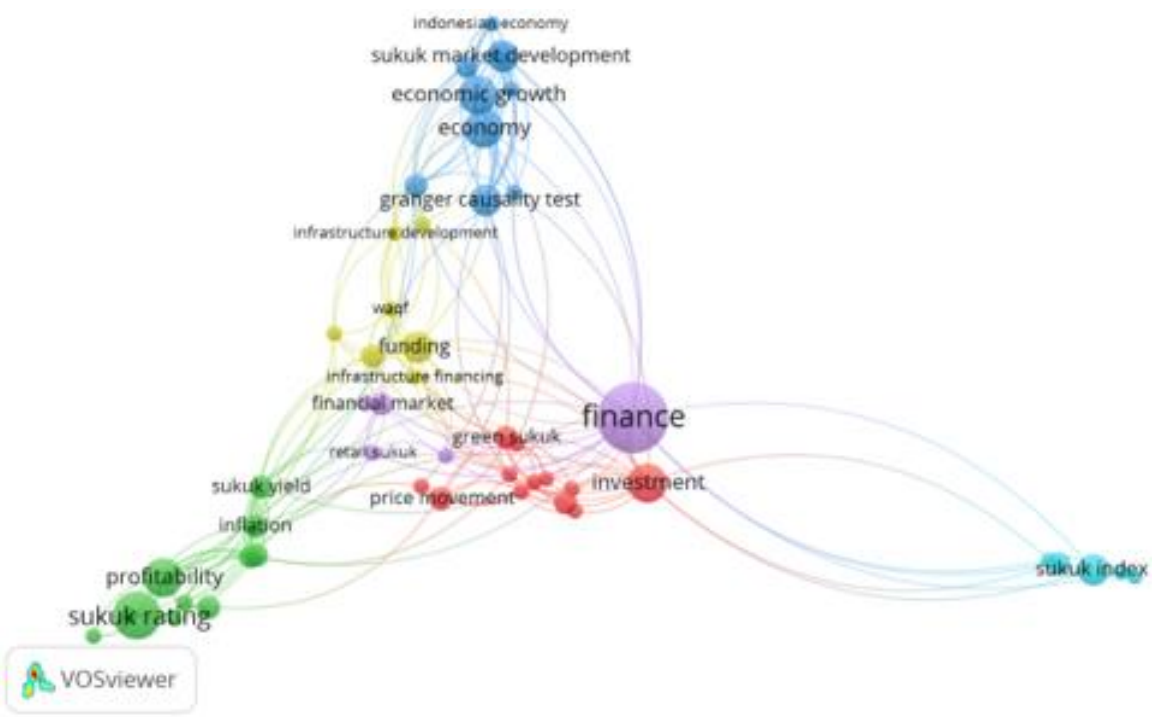

Figure 7 Bibliometric keyword mapping 
Figure 7 illustrates that some keywords that often appear in papers with the theme of sukuk in Indonesia are divided into 6 clusters, namely:

a. Cluster 1 in red color consists of 12 keywords: Climate Change, Energy Efficiency, Green Bond, Green Sukuk, Investment, Islamic Teaching, Macroeconomic Factor, Mutual Fund, Price Movement, Regulation, REPO, State Sukuk.

b. Green Cluster 2 consists of 11 keywords: IDX, Indonesia Stock Exchange, Inflation, Interest Rate, Multinominal Logistic Regression, Obligation, Profitability, Stock Return, Sukuk Issue, Sukuk Rating, Sukuk Yield.

c. Cluster 3 in blue consists of 10 keywords: Economy Growth, Economy, Empirical Evidence, GDP, Granger Causality Test, Impulse Response Function, Indonesian Economy, Islamic Banking, Islamic Stock Market, Sukuk Market Development.

d. Cluster 4 in yellow consists of 7 keywords: Funding, Ijarah Sukuk, Infrastructure Development, Infrastructure Financing, State Budget, Waqf, Zakat.

e. Cluster 5 purple color consists of 5 keywords: Finance, Financial Market, Retail Sukuk, State Retail Sukuk, Sukuk Ijarah.

f. The blue 6 cluster consists of 5 keywords: Bond Index, Fixed Income Investor, GCC, Policymaker, Sukuk Index. The keywords that are divided into 46 clusters above are arranged in colored circles that show cluster indicators. This data can be used to find out the trend of keywords in the last year. The bibliometric analysis shows several keywords that are widely used in the paper, which are the object of research. The more keywords that appear, the wider the circle is shown. Meanwhile, the line relationships between keywords show how much they are related to other keywords.

5. Bibliometric Index Mapping

Then, this study also obtained results in the form of an index that is often used by authors and is interrelated in the theme of sukuk in Indonesia which is related to Islamic economics as shown in the image below. Index that has the same color indicates a very close relationship.

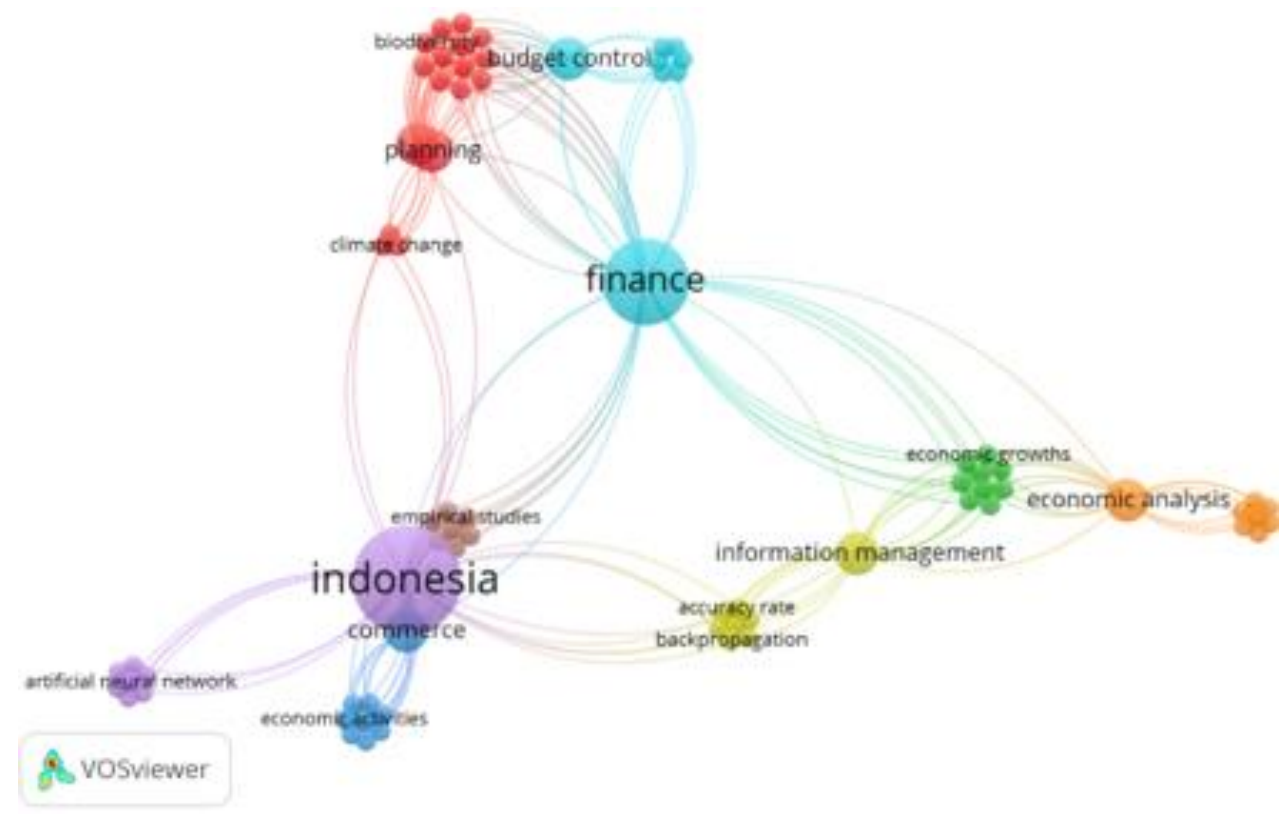

Figure 8 Bibliometric index mapping

Based on Figure 8. the results obtained, the lighter the color, the more recent the index is used. In the word index of the paper with the theme sukuk in Indonesia related to Islamic economics, there are several words that are used the most, namely Indonesia, followed by the word finance. 


\section{Discussion}

Table 3 Keyword, authors and institution with the highest publication

\begin{tabular}{|c|c|c|c|}
\hline Rank & $\begin{array}{l}\text { Keyword by } \\
\text { Occurrence }\end{array}$ & $\begin{array}{l}\text { Authors with The } \\
\text { Highest Publication }\end{array}$ & $\begin{array}{c}\text { Institution with The Highest } \\
\text { Publication }\end{array}$ \\
\hline 1. & Sukuk & Arundina $\mathrm{T}$. & $\begin{array}{l}\text { Faculty of Economics, Seikei } \\
\text { University, 3-3-1 Kichijoji } \\
\text { Kitamachi, Musashino City, Tokyo } \\
\text { 180-8633, Japan. }\end{array}$ \\
\hline 2. & Indonesia & Siswantoro D. & Heritage Trust Group, Singapore. \\
\hline 3. & Finance & Nagano M & $\begin{array}{l}\text { African Development Bank, Cote } \\
\text { D'Ivoire }\end{array}$ \\
\hline 4. & $\begin{array}{l}\text { Islamic } \\
\text { Finance }\end{array}$ & Bhuiyan R.A. & $\begin{array}{l}\text { Asian Development Bank Institute, } \\
\text { Tokyo, Japan. }\end{array}$ \\
\hline 5. & $\begin{array}{l}\text { Economic } \\
\text { Growth }\end{array}$ & Mat Ghani G. & $\begin{array}{l}\text { Energi Studies Institute, National } \\
\text { University of Singapore, Singapore. }\end{array}$ \\
\hline 6. & Inflation & Rahman M.P. & $\begin{array}{l}\text { Singapore Management University, } \\
\text { Singapore. }\end{array}$ \\
\hline 7. & $\begin{array}{l}\text { Islamic Stock } \\
\text { Market }\end{array}$ & Saiti B. & $\begin{array}{l}\text { Visiting Fellow at the Henley } \\
\text { Business School, University of } \\
\text { Reading, Reading, United Kingdom }\end{array}$ \\
\hline 8. & $\begin{array}{l}\text { Budget } \\
\text { Control }\end{array}$ & Qizam I. & $\begin{array}{l}\text { Istanbul Sabahattin Zaim } \\
\text { Universitesi, Istanbul, Turkey }\end{array}$ \\
\hline 9. & Profitability & Kasri R.A. & $\begin{array}{l}\text { Kulliyyah of Economics and } \\
\text { Management Sciences, } \\
\text { International Islamic University } \\
\text { Malaysia, Kuala Lumpur, Malaysia }\end{array}$ \\
\hline 10. & $\begin{array}{l}\text { Sustainable } \\
\text { Development }\end{array}$ & Mitsaliyandito R.Q. & $\begin{array}{l}\text { Department of Islamic Economics } \\
\text { and Finance, Istanbul Sabahattin } \\
\text { Zaim Universitesi, Istanbul, Turkey }\end{array}$ \\
\hline
\end{tabular}

\section{CONCLUSION}

\section{Conclusion}

This study aims to determine the extent of the development of the sukuk in Indonesia theme. The results show an increasing number of papers published on this theme in recent years from 2010 to 2021, more than 45 studies have been published on this theme. Bibliometric mapping shows that Arundina T. has written the most about sukuk in Indonesia. The institution that publishes the most papers related to sukuk in Indonesia is the Faculty of Economics, Seikei University, 3-3-1 Kichijoji Kitamachi, Musashino City, Tokyo 180-8633, Japan.. And the country that publishes the most papers related to sukuk in Indonesia is Indonesia. The sukuk research development map in Indonesia is divided into 6 clusters. Cluster 1 consists of 12 topics, cluster 2 consists of 11 topics, cluster 3 consists of 10 topics, cluster 4 consists of 7 topics, cluster 5 consists of 5 topics and cluster 6 consists of 5 topics. In the word index with the theme of sukuk in Indonesia, the most widely used word is Indonesia.

\section{Recommendation}

Recommendations that can be given to academics are to continue to develop scientific research on the theme of halal economics, especially by utilizing bibliometric results, for example using popular keywords, selecting references based on the most popular authors, institutions, countries, keywords and indexes. Academics can also expand the study of halal economics literature with more specific references, such as articles indexed by Scopus or use other software to produce more diverse bibliometric maps, such as R Biblioshiny. 


\section{REFERENCES}

Adam, N. J. \& Thomas, A. (2004). Islamic Bonds: Your Guide to Issuing, Structuring and Investingin Sukuk. London (UK), Euromoney Books.

Afshar, T. A. (2013). Compare and contrast sukuk (Islamic bonds) with conventional bonds, are they compatible?. Journal of Global Business Management, 9(1), 44-52.

Ahmed, E. R., Islam, M. A. \& Alabdullah, T. T. Y. (2014). Islamic sukuk: Pricing mechanism and rating. Journal of Asian Scientific Research, 4(11), 640-648.

Al-Barwary, S. M. I. (2007). Pasar Modal Menurut Pandangan Islam. Kuala Lumpur (MY), Jasmin Enterprise.

Atika, A., Saraswati, D., Chrisna, H., Nasution, H. A. P., \& Buana, S. P. (2018). Sukuk Fund issuance on sharia banking performance in Indonesia. International Journal of Civil Engineering and Technology, 9(9), 1531-1544.

Ayub, M. (2007). Understanding Islamic Finance. London (UK), Wiley.

Azhgaliyeva, D., Kapoor, A. \& Liu, Y. (2020). Green bonds for financing renewable energy and energy efficiency in South-East Asia: a review of policies. Journal of Sustainable Finance \& Investment, 10(2), 113-140.

Bhuiyan, R. A., Rahman, M. P., Saiti, B., \& Ghani, G. M. (2018). Financial integration between sukuk and bond indices of emerging markets: Insights from wavelet coherence and multivariate-GARCH analysis. Borsa Istanbul Review, 18(3), 218-230.

Bhuiyan, R. A., Rahman, M. P., Saiti, B., \& Ghani, G. M. (2019). Co-movement dynamics between global sukuk and bond markets: New insights from a wavelet analysis. International Journal of Emerging Markets, 14(4), 550-281.

[DSN MUI] Dewan Syariah Nasional Majelis Ulama Indonesia. (2003). Himpunan Fatwa Dewan Syariah Nasional. Jakarta (ID), Bank Indonesia.

Fasa, M. I. (2016). Sukuk: Teori dan Implementasi. Li Falah: Jurnal Studi Ekonomi dan Bisnis Islam, 1(1), 80-94.

Fatah, D. A. (2011). Perkembangan obligasi syariah (sukuk) di indonesia: Analisis peluang dan tantangan. Al-'Adalah, 10(1), 35-46.

Fauzi, F., Foo, D. \& Basyith, A. (2017). Islamic bond announcement: Is there any effect on returns?. Global Business Review, 18(2), 327-347.

Iqbal, Z., \& Mirakhor, A. (2011). An Introduction to Islamic Finance: Theory and Practice. New Jersey (US), John Wiley \& Sons.

Muhammad, A. B. A. (2000). Mu'jam Al Mustholahaat Al Iqtishodiyah Wal Islamiyah. Riyadh (SA), Maktabah Al'Abikan.

Muharam, H., Anwar, R. J. \& Robiyanto, R. (2019). Islamic stock market and sukuk market development, economic growth, and trade openness (the case of Indonesia and Malaysia). Business: Theory and Practice, 20, 196-207.

Nagano, M. (2016). Who issues Sukuk and when?: An analysis of the determinants of Islamic bond issuance. Review of Financial Economics, 31, 45-55.

Nagano, M. (2017). Sukuk issuance and information asymmetry: Why do firms issue sukuk?. PacificBasin Finance Journal, 42, 142-157.

Nazaruddin, A. W. (2010). Sukuk: Memahami dan Membedah Obligasi pada Perbankan Syariah. Yogyakarta (ID), Ar-Ruzz Media.

Royani, Y., Bachtar, M. A., Tambunan, K., Tupan, T., \& Alm, S. (2013). Pemetaan karya tulis ilmiah LPNK: Studi kasus LIPI dan BPPT (2004-2008). Jurnal Dokumentasi dan Informasi, 34(1), 128.

Shanmugam, B. and Zahari, Z.R. (2009). A Primer on Islamic Finance. Virginia (US), The Research Foundation of CFA Institute.

Siswantoro, D. (2012). Is "not-real" price lawful?: The case of Islamic (sukuk) mutual funds in Indonesia during financial crisis. Journal of Islamic Accounting and Business Research, 3(2), 163-177.

Suryomurti, W. (2011). Supercerdas Investasi Syariah. Jakarta (ID), Qultum Media.

AL-MUZARA'AH Special Issue 2022 
Tariq, A. A. (2004). Managing Financial Risks of Sukuk Structures. Loughborough (UK), Loughborough University.

Venardos, A. M. (2010). Current issues in Islamic banking and finance: Resilience and stability in the present system. World Scientific.

Yaumudin, U. K. (2008). Sukuk: Sebuah Alternatif Instrumen Investasi. Yogyakarta (ID), Kreasi Wacana.

Zubair, M. K. (2012). Obligasi dan sukuk dalam perspektif keuangan Islam: Suatu kajian perbandingan. Jurnal Ilmu Syari'ah dan Hukum, 46(1), 271-296. 